\title{
Olive growing and importance of plant nutrition in olive cultivars
}

\author{
Cansu Dölek Gencer ${ }^{1 *}$, Volkan Okatan ${ }^{2}$, Nazan Korkmaz ${ }^{3}$ \\ ${ }^{1}$ Cukurova University, Kozan Vocational High School, Kozan, Adana/Turkey \\ ${ }^{2}$ Usak University, Faculty of Agriculture and Natural Sciences, Department of Horticulture, Uşak, Turkey \\ ${ }^{3}$ Mugla Sitki Kocman University, Ortaca Vocational School, Ortaca, Muğla-Turkey
}

\section{ABSTRACT}

Olive has spread naturally in regions where have Mediterranean climate in both hemispheres. Olive, which has a great importance in the world and in our country, is a fruit species need to be studied. Olive, which is consumed as both fresh and olive oil, has a large importance in gastronomy and health sector. When quality and yield in olive are considered, the suitable conditions for the plant should be provided by paying attention to the breeding conditions. In this research, the general rules of olive growing are mentioned and importance of plant nutrition is emphasized, and the heights and temperature values that it can grow, soil cultivation, the improvement of the soil properties, the effects of nutrients on plant, nutrient uptake theories have been investigated. The aim of this study is to determine the functions of some plant nutrients and the nutrient intake of plants from soil. Since the olive is both immortal thanks to its tubers under the soil and is able to adapt to all conditions, it is a significant fruit species economically, but in order to increase yield and quality, plant nutrition should be given importance. This study will reveal the importance of plant nutrition and fertilization in olive and will lead the studies, which will be carried out concerning this issue in future.
\end{abstract}

\section{ARTICLE HISTORY}

Received: 20 November 2019

Accepted: 09 December 2019

\section{KEYWORDS}

Climate

Nutrition

Olive

Oil

\section{* CORRESPONDING}

cansudolek.90@gmail.com

\section{Introduction}

In Turkey, olive can be grown at altitudes between 800-1000 meters, but in lower height especially below 400 meters is more yielding. However, in Spain it can be grown in regions where have altitudes 250-1200 meters. While some olive varieties in the Atlas Mountains in North Africa can live up to $1600-1700$ meters, they can be found in 2000 meters in Argentina in the Southern Hemisphere (Ünsal, 2008). The places where is between $45^{\circ} \mathrm{C}$ the north and $30^{\circ} \mathrm{C}$ the south latitude, have $16-22^{\circ} \mathrm{C}$ average annual temperature, is above $-8^{\circ} \mathrm{C}$ the lowest temperature in winter, is resistant hot wind and have clay or calcareous soils, are the most optimal regions for olive breeding. Olive is a fruit species that is resistant to high temperatures, even drought and low soil moisture. Olive trees do not like excess wind, especially during flowering, fruit ripening and full oiling. The high humidity leads to disease and fruit disorders (pilling) on the tree (Ünsal, 2008).

Olive likes water, but is also resistant to drought. The olive can be grown in the Marmara region with an average annual precipitation of $900 \mathrm{~mm}$ and in the Black Sea region, which has a higher rainfall rate as well as in the Şanluurfa region, which has a very low rainfall average. When annual rainfall in olive falls below $750 \mathrm{~mm}$, the irrigation is required, otherwise the economic value of the product decreases (Ünsal, 2008). The olive tree, which is long-living, is resistant and can be propagated easily, was called as vivax oliva (long- living) by the ancient Romans.

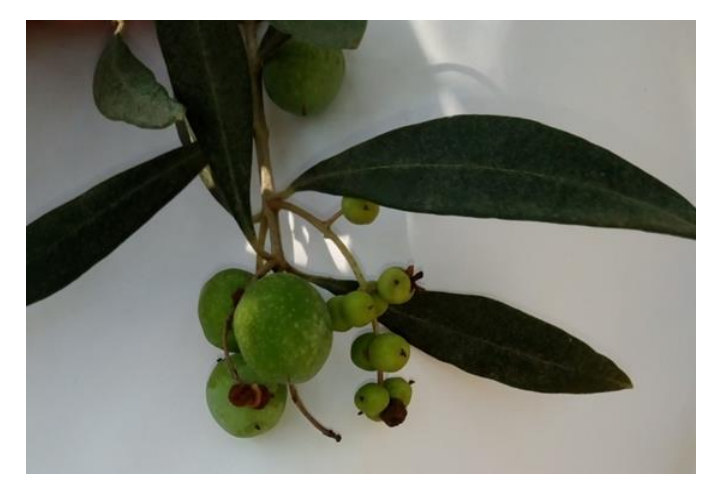

Figure 1. Regular and beaded growth in olive fruits (Cansu Dölek Gencer, unpublished thesis)

Olive likes water, but is also resistant to drought. The olive can be grown in the Marmara region with an average annual precipitation of $900 \mathrm{~mm}$ and in the Black Sea region, which has a higher rainfall rate as well as in the Şanluurfa region, which has a very low rainfall average. When annual rainfall in olive falls below $750 \mathrm{~mm}$, the irrigation is required, otherwise the economic value of the product decreases (Ünsal, 2008). The olive tree, which is long-living, is resistant and can be propagated easily, was called as vivax oliva (long- living) by the ancient Romans.

In the olive, the major root, which form constantly new roots, nourishes the stem and branches. Even if the trunk of
ORCID

Cansu Dölek Gencer: https://orcid.org/0000-0001-7628-0676

Volkan Okatan: https://orcid.org/0000-0001-5787-7573 
the tree dries, the trunk revives with shoots sprouting from its tubers and roots and emerges as a new tree. The olive that is evergreen and long-living and have hard wood is the most proper plant species againist erosion (Ünsal, 2008). If the soil cultivation is done with an appropriate technique, the biological activities of the soil increase. As a result the raw nutrients in soil mature, the maintaining of rainwater in the soil get easier and development of roots is better because of the soil aeration. The soil cultivation in the olive groves, the firstly is applied at a depth of $15 \mathrm{~cm}$ at the times when the soil gets annealed immediately after the harvest while the secondly is applied a depth of 10-12 cm 10 days before the tree blossoms in spring (Bülbül, 2008).

The most significant of organic fertilizers is farm manure. It is called a mixture, which forms from the stools and residues of the stables animals. It contains many nutrients. It should be mixed with some super phosphate fertilizer when the farm manure is stocked. In JanuaryFebruary, 50-200 kg farm manure is given per tree (depending on tree size) and mixed to the soil with soil cultivation. It regulates the physical, chemical and biological properties of soil. When the manure is given to the soil, the water holding capacity of the soil increases and the permeability is positively affected (Bülbül, 2008). The capacity of the plant to produce flowers of sufficient quantity and quality is significant in obtaining the product (Cuevas and Polito, 2004). Macro and micro nutrients play a significant role in the fruiting process. In this context, the importance of potassium in the development of grass pipe in female flower is emphasized (Holdaway-Clarke and Hepler, 2003). Potassium is a significant element in flowering and fruit formation. Foliar application of KNO3 has a positive effect on yield in olive. On the other hand boron is considered to be one of the significant micronutrients due to its effect on plant growth (Khayyat et al., 2007). In fact, the effects of boron application on the germination of farina and germination have been demonstrated. Leaf boron applications in olive cultivation are widely used because of its efficiency on phenology, yield, oil quality, shoot growth, crown volume, fruit attitude and hence efficiency (Larbi et al., 2011; El Khawaga, 2003). Product losses occur due to lack of nutrients in aquaculture in sandy soils. In the studies carried out in the leaves of olive trees, nitrogen, potassium, phosphorus and boron deficiency were determined (El Khawaga, 2007; Desoukaye et al., 2009; Acarsoy et al., 2011).

\section{Plant nutrition in olive cultivars}

In fruit trees and woody plants, there is a significant accumulation of nitrogen metabolism (uptake, transport, distribution and storage) (Titus and Kang, 1982; Kato, 1986; Roubelakis-Angelakis and Kliewer, 1992). In the preparation of fertilization programs, remobilization of nitrogen (re-transport) is a significant issue to be considered. In this context, in woody plants, nitrogen is remobilized and stored in roots and shoot shells at the end of the season (Titus and Kang, 1982; Irget et al., 2007). When the studies on the nutrition and fertilization of olives are examined in our country; a limited number of fertilization application studies have been seen such as the soil fertilization (Güner, 1969; Özelbaykal, 1995) foliar fertilization (Çetin and
Mendilcioğlu, 1992) and soil + foliar fertilization (Canözer and Çolakoğlu, 1985; Dikmelik et al., 1999). The studies on the subject are generally aimed at examining the relationship between; the determination of nutritional status of olives grown in different regions (Canözer, 1978; Zabunoğlu et al., 1977; Ak1llığlu, 1995; Toplu, 2000, Soyergin et al., 2002), the seasonal changes of nutrients (Eryüce, 1980; Püskülcü, 1981; Soyergin, 1993; Sarıfakıoğlu, 1995), the product and pruning, the amount of nutrients removed (Dikmelik, 1984), the nutrition status and yield (Fox et al., 1964) and quality (Seferoğlu, 1997; Irget et al., 2007).

The water content of the plant is between $80-95 \%$ and the rest is dry matter. The amount of this water varies depending on the species of plant, the amount of water in the growing environment, the temperature and the wind force. Analyzes related to the determination of dry matter content in the plant are carried out in samples obtained by grinding after the fresh plant samples are dried at $65-70{ }^{\circ} \mathrm{C}$ for $24-48$ hours. The ratio of carbon and oxygen in the total dry matter is very high, and they are followed by hydrogen. The amount of the other elements is lower, and shows significant differences between themselves and from plant to plant (Çokuysal et al., 2016). Green plants uptake a large proportion of carbon and oxygen from the atmosphere with their over-ground organs, and uptake hydrogen and a certain proportion of oxygen from water taken by their roots. In order to all other elements can be taken by the plant, they must be present in the root environment and soluble structure. The uptake and use of nutrients by plants depends on various factors such as light intensity, temperature, the amount of the water (Çokuysal et al., 2016).

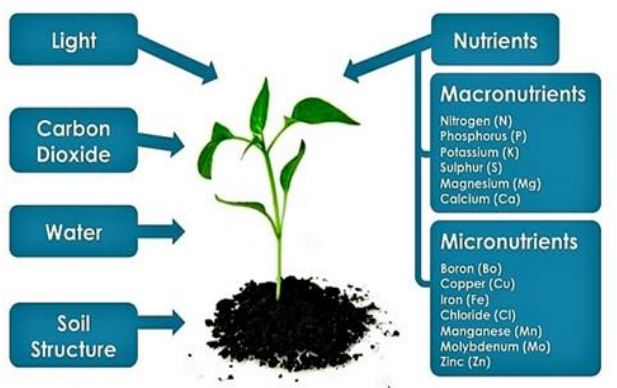

Figure 2. Plant nutrient requirements (Anonymous, 2019a)

Olive trees need more nutrients some periods such as the differentiation of the fruit buds (February-March), the beginning of the flowering (May), fruit set (June) and the hardening of the kernels (July-August). Nitrogen increases the quantity and quality of the crop and decreases the fruit fall. It ensures the formation of the new sprouts of the tree. The olive trees particularly need more nitrogen during flowering and fruit set. This requirement varies by depending on the size of the tree and the structure of the soil. Olive trees spend half of the nitrogen in these periods (flowering and fruit set). For this reason, the nitrogen fertilizer in irrigated fields should be applied three times: at 3 weeks before the flowering, the fruit set and the hardening of the kernels periods, but the in not irrigated fields, it is applied in late February and early March (Bülbül, 2008). 
Phosphorus improves the soil by increasing the activity of soil microorganisms. It increases flowering, fruit set and the fat content and the quality of the fruit. It increases the resistance of the tree against cold and frost, and it gives olive's unique color, aroma, taste and smell. However, it increases the resistance of the tree against cold and frost. Increases fat content and quality. Potassium is significant for flower and fruit formation. It ensure the saving of water of olive tree. Phosphorus and potassium fertilizers do not get lost by washing like nitrogenous fertilizers. So they should be applied in February. Plants uptake all the nutrients that they need from the soil in different ways. However, due to some reasons such as excessive chlorosis in the soil, deterioration of microorganism activities they cannot uptake these nutrients from the soil. Zinc $(\mathrm{Zn})$, manganese $(\mathrm{Mn})$, boron $(\mathrm{B})$, iron $(\mathrm{Fe})$, copper $(\mathrm{Cu})$, molybdenum (Mo), chlorine $(\mathrm{Cl})$, Nickel $(\mathrm{Ni})$ are micro nutrients. In the deficiencies of these micro nutrients, the flowering and fertilization problems in the trees, the disorders in the fruit and death backwards in the tree may appear (Bülbül, 2008). In this research, the general rules of olive growing are mentioned and importance of plant nutrition is emphasized, and the heights and temperature values that it can grow, soil cultivation, the improvement of the soil properties, the effects of nutrients on plant, nutrient uptake theories have been investigated.

\section{Results}

Carbonic acid theory: Carbonic acid $\left(\mathrm{H}_{2} \mathrm{CO}_{3}\right)$ is formed by the reaction of $\mathrm{CO}_{2}$, which formed by roots and microbial activity, with water. $\mathrm{H}^{+}$ions, which are separated from carbonic acid and become free standing, release by replacing cations in colloids and mix to the solution. Cations that mix the soil solution are taken to the root surface by replacing with $\mathrm{H}+$ ions on the root surface (Figure 3 ). The cations absorbed from the colloid surfaces must firstly pass into the soil solution. The role of this theory in the transport of plant nutrients to the roots is very low (Kahraman, 2012; Çokuysal et al., 2016).

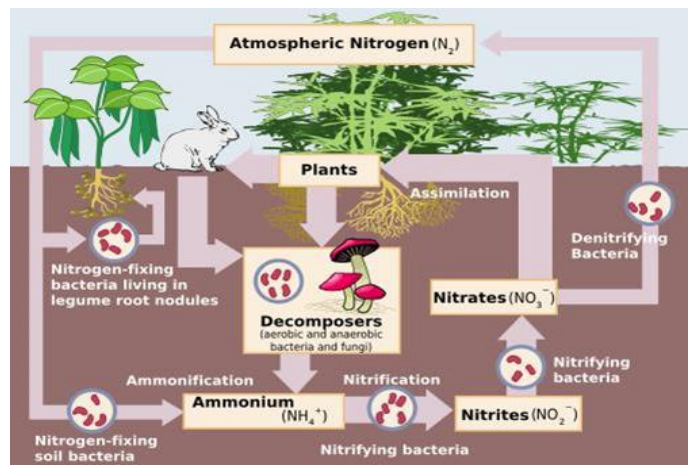

Figure 3. Cycle of nutrients in soil and movement in plants (Anonymous, 2019b)

Contact Exchange Theory: This theory suggests that absorbed nutrients are taken directly through the roots as a result of contact with the root surface of them (Figure 4). In this theory, there is no need for the presence of $\mathrm{CO}_{2}$ and ions do not need to pass into soil solution. Plant nutrients are transported from soil solution to the root zone by mass flow and diffusion. Mass flow: the nutrients, which is dissolved in soilis, is to carry-over to roots by convective flow of water (Eryüce, 2013). As the water absorption of the roots increases, the mass flow increases. The fastest mass flow occurs immediately after precipitation and irrigation, while the slowest mass flow occurs at the time of evaporation (Barber, 1974).

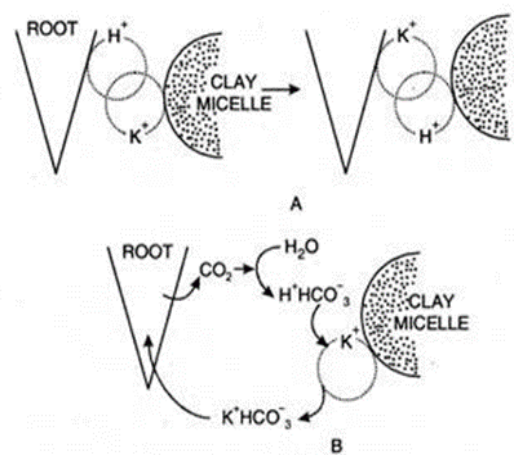

Figure 4. According to the theory of carbonic uptake of ions (Anonymous, 2019c)

Diffusion; When a nutrient is absorbed at high level in the root zone, the concentration of the nutrient in the around the root decreases and concentration difference occurs with to the external zone. As a result, the nutrient is transported from farther zone to the root zone by diffusion. It is stated that a large proportion of nutrients such as $\mathrm{N}, \mathrm{Ca}, \mathrm{Mg}$ and $\mathrm{S}$, which have high solubility, are transported to the root zone by mass flow, while a small portion of $\mathrm{P}$ and $\mathrm{K}$ required by the plant is uptaken with the mass flow (Barber, 1995; Çokuysal et al., 2016).

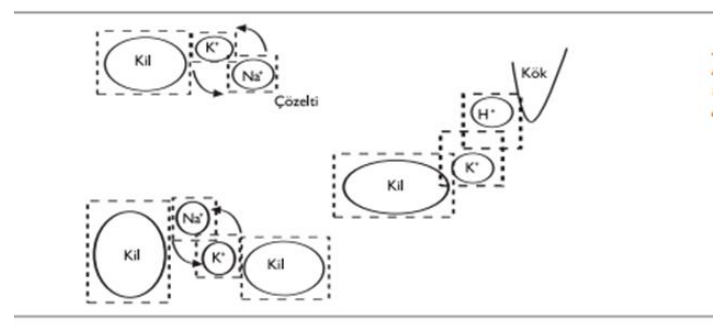

Figure 5. Displacement of ions according to the theory of interchange (Eryüce 2013)

High productivity in cultivation ranks first among production targets. Pollination is essential for fruit formation in stone fruit species. The capacity of the plant to produce sufficient quantity and quality of pollen is significant in obtaining the product. The quality of pollen is characterized by the vigor of the pollen and the germination power (Cuevas and Polito, 2004). As indicated by Wang et al. (2004), the physiology (especially germination and viability) of the pollen, is significant for plant breeding and adaptation (Khan and Perveen, 2006; Pinillos and Cuevas, 2008; Acarsoy et al., 2011). Due to the lack of the nutrient in sandy soils, the problem of the pollination in olive occur, and this results in product losses (Desoukaye et al., 2009; El Khawaga, 2007). In this context, 5, 50 and 100 ppm boric acid $(33.5 \% \mathrm{~B})$ applications in 12 years- old Arbequina, Bouteillan and 
Koroneiki olives are stated to increase fruit set (Desoukaye et al., 2009; Acarsoy etal., 2011).

Özkaya (2004), has reported that in the leaves of olive trees determined the deficiency of the nitrogen, potassium, phosphorus and boron. However, applications to young leaves significantly increase the risk of damaging the tissue before flowering. A effective method for foliar fertilization of olives has not been found. With multi-mineral leaf fertilizers prepared with olives at concentrations specific to $\mathrm{N}, \mathrm{P}, \mathrm{K}$ and / or B [(10-33-21+1.8B) and (8-16-40)] containing a completely organic fertilizer called Fertivant, positive effects have been obtained to increase fruit quality and yield especially in table olives. As a result of this work; it was recommended that before flowering, especially potassium, phosphorus and bor are applied, in the small fruit period potassium is applied

Mordoğan et al. (2013), have examined the effect of 0 , 75,150 and $225 \mathrm{~kg} /$ tree doses of organic fertilizer (bovine fertilizer) on the nutrient content of olive soils. They have noticed that these applications have significantly affected the content of $\mathrm{N}, \mathrm{K}, \mathrm{Ca}, \mathrm{Mg}, \mathrm{Cu}, \mathrm{Na}$ at $0-20 \mathrm{~cm}$ depth; $\mathrm{P}, \mathrm{K}, \mathrm{Ca}$, $\mathrm{Mn}, \mathrm{Cu}, \mathrm{Na}$ at 20-40 cm depth. The applications have not affected the Fe and $\mathrm{Zn}$ content of soils. $225 \mathrm{~kg} /$ tree dose of organic fertilizer has significantly increased the $\mathrm{K}$ and $\mathrm{Mg}$ content of soils. With the application of organic fertilizers, only $\mathrm{Fe}$ and $\mathrm{Na}$ contents of the soil showed significant changes over the years. It has been shown that Magnesium and zinc are effective in reducing the periodicity. Fertility and fertilization are negatively affected by zinc deficiency in trees, and zinc deficiency decreases the yield and fruit quality.

Zinc sulphate application of $0.3 \%-0.5 \%$ of the leaves to remove zinc deficiency is recommended in the period when the flowers occur and the fruit get hazelnut size (Gezerel, 1998; Kalenderoğlu, 2010). Jasrotia et al. (1999), have studied the effect of $\mathrm{N}$ and $\mathrm{K}$ fertilization in olive trees. Frantoio variety was used in this research. Four different $\mathrm{N}$ applications (250, 500, 750 and $1000 \mathrm{~g}$ per tree) were done, $\mathrm{K}$ application was applied as 250, 500 and $750 \mathrm{~g} \mathrm{~K}_{2} \mathrm{O}$ together with $500 \mathrm{~g} \mathrm{P}_{2} \mathrm{O}_{5}$ per tree which is the basic dose of $\mathrm{P}_{2} \mathrm{O}_{5}$. Fruit set, yield and fat content at $\mathrm{N}$ level of $750 \mathrm{~g}$ applied per tree were high. The highest yield was recorded from $500 \mathrm{~g} \mathrm{~K} 2 \mathrm{O}$ per tree application. Researchers have also observed that increased $\mathrm{N}$ levels result in a significant increasing in growth and yield. Thus, in order to achieve higher fruit set, yield and fat content in olive trees, $750 \mathrm{~g} \mathrm{~N}$ and $500 \mathrm{~g} \mathrm{~K}_{2} \mathrm{O}$ application per tree were found to be optimal (Kalenderoğlu, 2010).

\section{Conclusion}

Topography, climate and soil properties and plant nutrition are very significant when plant cultivation is planning. The plant cultivation can never be considered without fertilization. Plants get all the nutrients that they need from the soil in various ways. Fertilization is to improve the physical, chemical and biological properties of soils and is to reinforce the nutrients that the plant cannot take due to certain conditions. Soil cultivation and organic fertilization support synthetic fertilizers. At the same time, it provides more balanced growth, durability, high yield and quality in trees. The aim of this study is to determine the functions of some plant nutrients and the nutrient intake of plants from soil. Since the olive is both immortal thanks to its tubers under the soil and is able to adapt to all conditions, it is a significant fruit species economically, but in order to increase yield and quality, plant nutrition should be given importance. This study will reveal the importance of plant nutrition and fertilization in olive and will lead the studies, which will be carried out concerning this issue in future.

\section{References}

Acarsoy, N., Eryüce N., Mısırlı, A., Kılıç, Ö. G., Kılıç, H., \& Ertuğrul, A. (2011). Farklı bileşimlerde bor, azot ve potasyumlu yaprak gübrelerinin Domat zeytin çeşidinde çiçek tozu canlılığ 1 , çimlenmesi ve meyve tutumu üzerine etkileri. Zeytin Bilimi, 2 (2), 49-57.

Akıllığlu, A. (1995). Aydın yöresi zeytinliklerinin beslenme durumu. Türkiye II. Ulusal Bahçe Bit. Kong. 3-6 Ekim, Cilt I: 741-745, Adana.

Anonymous. (2019a). https://sswm.info/factsheet/nutrientrequirements

Anonymous. (2019b). https://www.ducksters.com/science/ecosystems/nitrogen_c ycle.php

Anonymous. (2019c). http://cdn.biologydiscussion.com/wpcontent/uploads/2016/02/clip image 002-176.jpg.

Barber, S. A. (1974). Influence of the plant root on ion movement in the soil. In E.W. Carlos ed. The plant root and its environment. Univ. Press of Virginia, USA.

Barber, S. A. (1995). Soil nutrient bioavailability: A mechanistic approach, 2nd ed. John Wiley and Sons, NY.

Bülbül, E. (2008). Her yönüyle zeytincilik. İnkılap Yayıncılık, 158-161. ISBN: 978-975-10-2647-7.

Canözer, Ö. (1978). Ege Bölgesi önemli zeytin çeşitlerinin besin element statüleri ve toprak-bitki ilişkileri. Ege Üniversitesi Fen Bilimleri Enstitüsü, Uzmanlık Tezi, Bornova, İzmir, 239s.

Canözer, Ö., \& Çolakoğlu, H. (1985). Memecik zeytin çeşidinde yapraktan ve topraktan uygulanan gübrelemenin verim ve kaliteye etkilerinin araştırılması. Zeytincilik Araş. Ens. Proje Sonuç raporu, Bornova-İzmir.

Cuevas, J., \& Polito, V. S. (2004). The role of staminate flowers in the breeding system of Olea europaea (Oleaceae): an andromonoecious, wind-pollinated taxon. Annals of Botany, 93(5), 547-553.

Çetin, A., \& Mendilcioğlu, K. (1992). Ayvalık yağlık zeytin çeşidinde verim ve bazı kalite özelliklerine yapraktan gübre uygulamasının etkisi üzerine bir araştırma. Türkiye I. Ulusal Bahçe Kong 13-16 Ekim, Cilt 1: 155-158, İzmir.

Çokuysal, B., Anaç, D., Eryüce, N., Esetlili Çolak, B., Özkan, C. F., \& Tepecik, M. (2016). Topraksı tarım ve bitki besleme teknikleri. Nobel Yayıncılık, 29-31. ISBN: 978605-320-298-1.

Desoukaye I.M., Haggag, L.F., Abd El -Migeed, M.M.M., Kishk, Y.F.M., \& El- Hady, E.S. (2009). Effect of boron and calsium nutrients sprays on fruit set, oil content and oil quality of some olive oil cultivars. World J. Agric. Res., 5(2), 180-185.

Dikmelik, U., Püskülcü, G., Altuğ, M., \& Irget, M. E. (1999). The effect of KNO3 application on yield and fruit quality of olive in improved crop quality by nutrient management (Editors: D. Anaç and P. Martin-Prével), Kluwer Academic Publishers, 77-80.

Dikmelik, Ü. (1984). A research on determination of amount of 
nitrogen, phosphorus and potassium removed from soil by grain and pruning residues in Memecik olive trees of different ages. Olive Research Inst. Publication, (31).

El Khawaga, A. S. (2007). Improving growth and productivity of Manzanillo olive trees with foliar application of some nutrients and girdling under sandy soil. J. Appl. Sci. Res., 3(9), 818-822.

El Khawaga, A. S. (2003). Effect of girdling and foliar application of some nutrients on growth, flowering, yield and fruit quality of manzanillo olive trees grown in sandy soil. J. Agric. Sci., Mansoura Univ., 28 (3), 2124-2124.

Eryüce, N. (1980). Ayvalık bölgesi yağlık zeytin çeşidi yapraklarında bazı besin elementlerinde bir vejetasyon periyodu içindeki değişmeler. E. Ü. Zir. Fak. Dergisi, 17 (2): 209-222.

Eryüce, N. (2013). Toprak bilgisi ve bitki besleme. (Ed. Ünver ve Anaç) A.Ü. Yayın No: 2302, Açıköğretim Fakültesi Yayın No: 1299, Ankara.

Fox, R.L., A. Aydeniz, \& Kacar, B. (1964). Soil and tissue tests for predicting olive yields in Turkey. Empire Jour. Of Exp. Hort. 32(125), 84-91.

Gezerel, Ö. (1998). Meyve ağaçlarının gübrelenmesi ve sorunları. T.C. Başbakanlık Devlet Planlama Teşkilatı Müsteşarlığı, Çukurova Üniversitesi Pozantı Tarımsal Araştırma ve Uygulama Merkezi, Ülke Ölçeğinde Meyvecilik Geliştirme Entegre Projesi Eğitim Programı II, Adana.

Güner, H. (1969). Zeytinin kimyasal yaprak yapısı ile ürün verimi arasındaki ilişkilere dair bir araştırma. Ege Üniv. Zir. Fak. Yayın No:155, Bornova, İzmir.

Holdaway-Clarke, T. L., \& Hepler, P. K. (2003). Control of pollen tube growth: role of ion gradients and fluxes. New Phytol., 159(3), 539-563.

Irget, M. E., Kılıç, C. C., Bayaz, M., \& Özer, K. (2007). Azotlu gübrelemenin zeytinde verim ve kaliteye etkisi. ADÜ Ziraat Fakültesi Dergisi, 4(1-2): 27-33.

Jasrotia, A., Singh, R.P., Singh, J.M. \& Bhutan, V.P. (1999). Response of olive trees to varing levels of $\mathrm{N}$ and $\mathrm{K}$ fertilisers. Acta Hortic., 474, 337-340.

Kahraman, M. R. (2012). Bitki besleme. Gübretaş rehber kitaplar dizisi: 2, Ankara.

Kalenderoğlu, H. (2010). Gemlik zeytin çeşidinde dal eğme ile birlikte yapraktan azot, potasyum ve magnezyum uygulamalarının meyve verimi ve kalite üzerine etkisi. Çukurova Üniversitesi Fen Bilimleri Enstitüsü Yüksek Lisans Tezi, 2010.

Kato, T. (1986). Potato breeding by cell fusion. Potato Sci. 6: 80-81.

Khan S.A., \& Perveen, A. (2006). Germination capacity of storaged polen of Abelmoschus esculenthus L. (Malvaceae) and their maintenance. Pak. J. Bot., 38 (2): 233-236.

Khayyat M., Tafazoli, E., Eshghi, S., \& Rajaee, S. (2007). Effect of nitrogen, boron, potassium and zinc sprays on yield and fruit quality of date palm. American Eurasian J. Agric \& Environ. Sci. 3, 289-296.

Larbi, A., Gargouri, K., Ayadi, M., Dhiab, A., \& Msallem, M. (2011). Effect of foliar boron application on growth, reproduction, and oil quality of olive trees conducted under a high density planting system. J. Plant Nutr., 34, 2083 2094.
Mordoğan, N., Ceylan, Ş., Delibacak, S., Çakıcı, H., Günen, E., Pekcan, T., \& Çolak, B. (2013). Organik gübrelemenin zeytin yetiştirilen kumlu-tınlı topraktaki besin elementi içeriğine etkisi. ADÜ Ziraat Derg., 10(1), 7 - 132013.

Özelbaykal, S. (1995). Çukurova bölgesinde yetiştiriciliği yapılan zeytinlerde azotlu gübrelerin verim, kalite ve bitki besin maddeleri içerikleri üzerine etkileri. Ç.Ü. Fen Bil. Ens. Bahçe Bitkileri Anabilim Dalı, Adana (Doktora Tezi).

Özkaya, M. T. (2004). Gemlik zeytin (Olea europaea L.) çeşidinde farklı dönemlerde uygulanan bazı yaprak gübrelerinin meyve verim ve kalitesi üzerine etkileri. Tar. Bil. Der. 10(3), 353-357.

Pinillos, V., \& Cuevas, J. (2008). Standardization of the fluorochromatic reaction test to assess pollen viability. Biotech Histochem., 83(1), 15-21.

Püskülcü, G. (1981). Memecik zeytin çeşidinde makro ve mikro besin elementlerinin mevsimsel değişimlerinin incelenmesi. Zeytincilik Araş. Enst.; Bornova, İzmir. (Uzmanlık Tezi).

Roubelakis-Angelakis, K. A., \& Kliewer, W. M. (1992). Nitrogen metabolism in grapevine. Hortic. Rev. 14: 407452.

Sarıfakıoğlu, M. C. (1995). Bazı zeytin çeşitlerinde yaprak ve meyvede mineral besin maddelerinin mevsimsel değişimi ve ürün ile kaldırılan besin maddelerinin belirlenmesi, Ege Üniv. Fen Bilimleri Enst. Toprak Anabilim Dalı, Bornova, İzmir (Doktora Tezi).

Seferoğlu, S. (1997). Ayvalık ve Edremit yöresinde yetiştirilen ayvalık zeytin çeşidinin beslenme statüsü ile kimi kalite öğeleri arasındaki ilişkiler. Ege Üniv. Fen Bilimleri Ens. Toprak Anabilim Dalı, Bornova, İzmir (Doktora Tezi).

Soyergin, S. (1993). Bursa Yöresi Gemlik Çeşidi Zeytinlerinin Bazı Besin Elementleri İçeriği ve $\mathrm{Bu}$ Elementlerin Mevsimsel Değişimleri. Uludağ Üniv. Fen Bilimleri Enst. Toprak Anabilim Dalı, Bursa (Doktora Tezi).

Soyergin, S., Moltay, I., Genç, C., Fidan, A.E. \& Sutçu, A.R. (2002). Nutrient Status of Olives Grown in the Marmara Region. Acta Hortic., 586, 375-379

Titus, J. S. \& Kang, S. M. (1982). Nitrogen metabolism, translocation and recycling in apple trees. Hort, Rev. 4: 204246.

Toplu, C. (2000). Hatay ili değişik üretim merkezlerindeki zeytinliklerin verimlilik durumları, fenolojik, morfolojik ve pomolojik özellikleri ile beslenme durumları üzerinde araştırmalar. Çukurova Üniv. Fen Bilimleri Enst. Bahçe Bitkileri Anabilim Dalı, Adana (Doktora Tezi).

Ünsal, A. (2008). Ölmez ağacın peşinde. YKY Yayınları Kitap Sf. 79-81. ISBN: 978-975-08-0625-5.

Wang, Z. Y., Ge, Y., Scott, M., \& Spangenberg, G. (2004). Viability and longevity of pollen from transgenic and nontransgenic tall fescue (Festuca arundinacea)(Poaceae) plants Am. J. Bot., 91, 523-530.

Zabunoğlu, S., Hatipoğlu, F., \& Yenicesu, İ. (1977). Bursa ilinde yetiştirilen sofralık gemlik çeşidi zeytin ağaçlarının makro ve mikro besin maddeleri durumu. Tübitak, VI. Bilim Kong. Tebliğleri, Ankara. 